\title{
Hannah Arendt e os elementos constitutivos de um conceito não liberal de cidadania
}

\author{
Hannah Arendt and the constitutive elements \\ of a non-liberal concept of citizenship
}

\section{Cesar Augusto Ramos}

Doutor em Filosofia Política pela Universidade Estadual de Campinas (Unicamp), professor do Programa de Pós-Gradução em Filosofia da Pontifícia Universidade Católica do Paraná (PUCPR), Curitiba, PR - Brasil, e-mail: cauramos@uol.com.br

\section{Resumo}

O artigo tem por objetivo empreender uma análise de conceito de cidadania com base em determinados elementos da teoria política de Hannah Arendt: a liberdade, a ação, a pluralidade e o espaço público. São elementos necessários à constituição de um conceito sob a sua forma especificamente política, o qual pode ser enunciado nos seguintes termos: cidadania é a ação política de indivíduos que buscam na esfera do espaço público da pluralidade a realização da liberdade. Na sua abrangência, este conceito pode ser interpretado como uma crítica diante das deficiências da tese liberal da cidadania, corrigindo as suas limitações. Ao mesmo tempo, ele lança perspectivas de proximidade (e, também, de afastamento) com a teoria política do republicanismo.

Palavras-chave: Cidadania. Liberalismo. Liberdade. Pluralismo. Republicanismo. 


\begin{abstract}
The objective of this article is to undertake an analysis of the concept of citizenship based on certain elements of Hannah Arendt's political theory: freedom, action, plurality and public space. Those elements are necessary to compose a concept under its specific political form, which can be enunciated as follows: citizenship is the political action of individuals who seek in the sphere of the public space of plurality the achievement of freedom. In its extension, this concept may be interpreted as a critique in front of the deficiencies of the liberal thesis of citizenship, amending its limitations. Simultaneously, it casts perspectives of proximity (and also, of remoteness) in relation to the political theory of republicanism.
\end{abstract}

Keywords: Citizenship. Liberalism. Freedom. Pluralism. Republicanism.

A riqueza de uma teoria política pode ser avaliada pelas possibilidades de análise que ela promove no conjunto dos seus pressupostos metodológicos e contribuições conceituais. A filosofia política de H. Arendt é um bom exemplo nesta perspectiva, ao suscitar uma alternativa de análise do conceito (político) de cidadania, cujo empreendimento teórico permite superar as deficiências da concepção liberal, centrada na tese da cidadania como intitulação de direitos. Esta concepção tem por base um conceito negativo de liberdade e vincula-se à ideia da proteção jurídica dos direitos - o que resulta em compreender a cidadania como meio ou instrumento para o livre exercício do pluralismo ético, político e econômico dos cidadãos, sobretudo no âmbito privado da sociedade civil. Assim, pretende-se, primeiramente, abordar esta perspectiva de análise que o liberalismo - especialmente o liberalismo político de Rawls - confere à cidadania (I).

Em seguida (II), o foco se volta à investigação de elementos que permitem a constituição de um conceito não liberal de cidadania sugerido pela filosofia de Arendt. Esta tarefa, por si só desafiadora diante do predomínio da teoria liberal, consiste em examinar de que modo determinados elementos conceituias - a liberdade, a ação, a pluralidade e o espaço público - presentes na teoria de Arendt permitem a constituição de um conceito de cidadania sob a sua forma especificamente política. Ainda que a autora não formule de forma explícita tal conceito, é possível enunciá-lo nos seguintes termos: cidadania 
é a ação política de indivíduos que buscam no âmbito do espaço público da pluralidade a realização da liberdade.

Por último (III), pretende-se destacar que este conceito - na abrangência de compreensão da dimensão política da convivência humana, no sentido de privilegiar a autonomia do político e o seu fundamento, a liberdade - pode ser interpretado como uma crítica às deficiências da tese liberal da cidadania, corrigindo as suas limitações. Esta crítica permite avaliar a relação de Arendt com o liberalismo no que diz respeito, mormente, à concepção de liberdade e de pluralidade. Enfim, nessa linha, é possível analisar também de que modo a posição arendtiana lança perspectivas de proximidade (e, também, de afastamento) com o republicanismo.

\section{I}

O ideal político de organização das sociedades modernas girou em torno de determinados princípios que representaram - e ainda representam valores normativos para a vida do homem em sociedade, e que afetam o sentido e a finalidade da convivência humana. No campo jurídico e moral eles estão representados pela valorização dos direitos humanos e da liberdade individual. No âmbito moral, pela ênfase ao pluralismo na diversidade dos modos de vida dos indivíduos, que se responsabilizam pelos seus próprios destinos e pelos contratos livremente elaborados, bem como na adesão às diversas concepções de bem, convicções e opiniões em matéria de moral e de religião. No que diz respeito ao poder público - associado à ideia de um governo limitado e de leis, com a consequente rejeição de um poder discricionário e arbitrário -, o Estado deve ser neutro relativamente a essas concepções de bem. Em relação à vida privada, objetivo precípuo dos cidadãos, sobretudo na defesa da propriedade privada, deve se pautar pelo respeito ao gozo particular dos ganhos materiais da sociedade. Estes princípios são considerados essenciais, e a tradição filosófica no campo da ética, da política e do direito consagrou-os como os mais adequados para as sociedades modernas.

Contudo, esse ideário ético-político surgiu no cenário histórico como o apanágio de uma forma específica de compreender a política - o liberalismo -, e a sua finalidade exigiu a presença de um determinado modo (privado) de vivê-la por parte de indivíduos que se qualificam como cidadãos. Para cumprir esse escopo, a filosofia liberal definiu a cidadania como intitulação de direitos. Essa fórmula simples, mas abrangente, remete a cidadania ao 
âmbito dos interesses e direitos individuais: ela está garantida quando nenhum direito é violado ou ameaçado. ${ }^{1}$ A cidadania significa o status jurídico pelo qual o indivíduo, como membro de uma comunidade política - denominada juridicamente de Estado-nação -, possui prerrogativas e direitos previstos nas Constituições dos Estados de Direito. O alcance e os limites da ação da cidadania estão definidos em leis, e a sociedade política é apenas o porta-voz dos direitos, cuja finalidade é a proteção dos interesses pré-políticos.

O sentido da cidadania passa, então, a ser apreciado como instrumento para a realização de direitos, sobretudo as liberdades fundamentais, pois não vincula nenhum bem político ao seu estatuto conceitual. Assim concebida, ela resultou em meio pelo qual o indivíduo faz valer a sua condição de titular de direitos anteriores à esfera política, sobretudo diante do Estado. Um dos elementos de fundamental importância para os objetivos dessa instrumentalidade é, precisamente, a liberdade individual que passa a ser entendida como a esfera de ação em que o indivíduo não está impedido por quem quer que seja de fazer ou deixar de fazer aquilo que ele deseja - a chamada liberdade negativa. ${ }^{2} \mathrm{~A}$ ação da cidadania é vista como meio para assegurar a liberdade individual da interferência de outrem, especialmente do Estado, não autorizada pela lei.

Na ênfase a esta forma de liberdade, o liberalismo desenhou a figura de agentes conscientes livres que possuem um valor na sua individualidade,

1 A obra de T.H. Marshall, Citizenship and Social Class, escrita em 1949, constitui um marco nos estudos da cidadania como o status do indivíduo para ter direitos, enquanto membro da sociedade, assegurados por lei. Marshall compreende a cidadania em três categorias: direitos civis, direitos políticos e direitos sociais, conforme a evolução histórica da criação dos direitos civis no século XVIII, e se estende para o século XIX com os direitos políticos e alcança, no século XX, os direitos sociais. Hoje, pode-se acrescentar uma quarta geração de direitos - os chamados direitos difusos - como aqueles que se referem ao meio ambiente preservado, por exemplo.

2 No seu ensaio Dois conceitos de liberdade, I. Berlin (1998) analisa duas concepções de liberdade. No sentido negativo, a liberdade é compreendida como ausência de impedimentos, barreiras ou restrições externas para que alguém possa fazer ou deixar de fazer aquilo tem desejo de fazer. É esta concepção de liberdade que o liberalismo vai defender. A outra concepção de liberdade (positiva), inspirada em teóricos como Rousseau, Kant, e outros, procura definir a política, o poder e ação humana em termos de uma vontade legítima fundamentada na autonomia do querer. No sentido positivo, a liberdade decorre de um desejo do indivíduo de ser seu próprio senhor. Este conceito de liberdade opera com a ideia de autonomia da vontade e de independência do sujeito como condição básica para a realização do ser humano na autodeterminação de suas ações.

Rev. Filos., Aurora, Curitiba, v. 22, n. 30, p. 267-296, jan./jun. 2010 
independentemente de outros indivíduos ou de vínculos societários, e cujo atributo moral lhes permite agir de acordo com concepções particulares de bem, tão diversas quanto são as preferências pessoais nas escolhas destas concepções, orientando as suas vidas em conformidade com elas.

Uma hipótese crucial do liberalismo consiste no fato de os cidadãos iguais terem concepções diferentes, e efetivamente incomensuráveis e irreconciliáveis, do bem. Numa sociedade democrática moderna, a existência de modalidades de vida tão diversas é considerada uma circunstância normal que só pode ser suprimida pelo uso autocrático do poder do Estado (RAWLS, 2000, p. 160-161).

O poder público não deve tomar partido em nenhuma concepção de bem. Deve, antes, defender a ideia de que os indivíduos, a partir das suas convicções, têm a liberdade de criar e de realizar o que é melhor para eles, sem a imposição de terceiros ou do Estado, que deve ser imparcial em relação à diversidade das concepções de bem e de vida que os indivíduos revelam e desejam no uso da sua liberdade. Trata-se da tese da equidistância ética, mediante a qual a ausência de um bem comum substantivo é absolutamente indispensável para a existência de uma democracia pluralista e multicultural, e que a lei deve resguardar. Constitui, portanto, um traço essencial para a filosofia liberal a defesa do pluralismo, cujo fato cultural e ético requer uma perspectiva política e jurídica equidistante de respeito às diversas concepções racionais de bem. O liberalismo está, destarte, assentado no postulado central do fato do pluralismo, como reiteradamente salienta J. Rawls.

A sociedade realiza no conjunto o interesse coletivo, mas apenas como consequência da busca dos proveitos individuais dos seus agentes. Se as ações dos indivíduos são interessadas e mesmo egoístas, não há nenhum sentido em direcioná-las com vistas à realização de um bem comum. Uma possível "virtude" pública na promoção deste bem será alcançada no conjunto, como o resultado das ações individuais quando os sujeitos, mesmo sem intenção, realizam práticas sociais coletivas consideradas "virtuosas", mas adstritas aos seus interesses. Formas comunitárias de sociabilidade que estimulam a promoção imperativa de um bem ético-político comum devem, assim, ser abandonadas.

Ainda que revelando dimensões conflituosas que ocorrem na esfera da sociabilidade privada na afirmação e busca da diversidade de fins particulares - consequência de uma sociedade pluralista, na qual concepções rivais de pensamento e de modos de vida têm espaço e incitam à competição - a 
sociedade pode ser compreendida como uma associação de agentes cooperativos que possuem planos e concepções diferentes de vida.

A cooperação social visa sempre o benefício mútuo e isso implica que envolva dois elementos: o primeiro reside numa noção partilhada de justos termos da cooperação, os quais se pode razoavelmente esperar que cada participante aceite desde que todos os outros igualmente os aceitem. Os justos termos da cooperação articulam uma idéia de reciprocidade e de mutualidade: todos aqueles que cooperam têm de beneficiar, ou partilhar encargos, em alguma forma apropriada definida em função de um ponto de referência adequado de comparação (RAWLS, 1997, p. 285).

Na perspectiva do liberalismo político de Rawls, a ideia da mutualidade cooperativa representa um elemento social importante na sua teoria. Se a sociedade se caracteriza como um "sistema equitativo de cooperação", o elemento societário intersubjetivo é definido na base da associação dos interesses individuais. Ao não se fundamentar numa doutrina exaustiva moral, religiosa ou filosófica, a teoria da justiça como equidade "abandonaria o ideal da comunidade política e trataria a sociedade como um conjunto de associações ou de indivíduos distintos que só cooperariam em vista do seu próprio interesse, individual ou associativo, sem compartilhar nenhum fim último" (RAWLS, 2000, p. 319-320). É bem verdade que os indivíduos, deixando de lado o egoísmo e a inveja, estão dispostos a encontrar o melhor sistema de cooperação. Ainda assim, eles agem movidos pela melhor razoabilidade segundo o julgamento de cada um, e que consiste em perguntar quais são os "termos justos da cooperação social" entre cidadãos que se caracterizam como seres livres e iguais. Os termos justos, mas não necessariamente os verdadeiros, e nem os moralmente corretos, uma vez que a verdade é uma apreciação relativa a uma concepção de bem dos diferentes indivíduos, segundo as escolhas racionais que cada um define para si, a partir de um projeto racional de vida.

Para Rawls, pouco importa se a união social é o resultado de uma trama de intercâmbios interpessoais que tecem o campo da cooperação, ou se é compreendida como o resultado de interesses contratuais. $\mathrm{O}$ decisivo numa teoria da justiça como equidade, na qual determinados bens primários são estabelecidos segundo princípios de justiça, é a recusa do ideal de comunidade. Uma ordem social justa não descarta bens socialmente partilhados, constitutivos para a cooperação. O que se rejeita é a ação reguladora deste ideal sobre as liberdades individuais a partir de uma ideia unificadora 
(religiosa, moral ou filosófica) da vida social das sociedades, marcadas pela tolerância e pelo pluralismo.

Uma vez garantidos os bens primários - os mesmos direitos básicos, liberdades e oportunidades, renda e riqueza e as bases do sentimento de dignidade -, os cidadãos, como pessoas livres e iguais, buscam suas próprias e diferentes concepções de bem. A política deve ser a mera expressão de mecanismos que melhor executam a administração de uma teoria da justiça assim constituída. A função do Estado é assegurar, por meio de princípios de justiça, a igualdade formal dos cidadãos, sem esposar nenhuma preferência particular de bem. Destarte, é preciso estabelecer, preliminarmente e de forma contratual, princípios equitativos de uma teoria da justiça que regulam o funcionamento das instituições de base de uma sociedade. A lei pública, objeto de zelo da cidadania e para a qual o cidadão deve dirigir os seus esforços, representa apenas meio para assegurar a liberdade individual, a pluralidade das opiniões e a diversidade dos modos de vida, a propriedade privada, a concorrência econômica e os contratos livremente pactuados.

O liberalismo sustenta a ideia de que os homens, na realização dos objetivos da vida privada e no respeito às concepções pessoais do bem, e na medida em que não são suficientemente escrupulosos para observar o princípio da liberdade (negativa), têm necessidade do Estado e das leis, mas apenas para garantir os direitos e o respeito recíproco da liberdade entre eles. A liberdade pode ser limitada pelo poder político, mas só no interesse da própria liberdade. O poder do Estado necessita, ele também, ser controlado, e a sua esfera de ação voltada para o interesse e direitos dos indivíduos. Essa regra política foi enunciada por Locke e permanece, ainda hoje, válida para o liberalismo.

Todo o poder que o governo tem, destinando-se tão-só ao bem da sociedade, da mesma forma que não deve ser arbitrário ou caprichoso, também deve ser exercido mediante leis estabelecidas e promulgadas, para que não só os homens possam saber qual o seu dever, achando-se garantidos e seguros dentro dos limites das leis, como também para que os governantes, mantidos dentro de limites, não fiquem tentados pelo poder que têm nas mãos a entregá-lo para fins tais e mediante medidas tais de que os homens não tivessem conhecimento nem aprovassem de boa vontade (LOCKE, 1973, § 137, p. 94).

A transferência para a autoridade governamental (jurídica e política) do poder de estabelecer os limites legítimos da ação impeditiva dos outros 
e a instituição de regras que protegem a esfera privada das condutas individuais são inerentes à concepção liberal, pois se trata de garantir os direitos dos indivíduos, particularmente a liberdade de elaborar e viver uma determinada concepção racional de bem, e assegurá-la dentre a pluralidade das concepções divergentes que coexistem na diversidade dos modos de vida das pessoas. $\mathrm{O}$ cidadão possui o direito de promover o seu próprio interesse, e as instituições sociais, políticas e jurídicas devem assegurar essa prerrogativa como um valor essencial da cidadania.

De acordo com este ponto de vista, a cidadania não comporta nenhum valor político substancial baseado na ideia de um bem comunitário com vistas à sua realização no espaço público. O único valor possível, a partir do qual é viável constituir as condições essências mínimas para a cidadania, é a construção procedimental de princípios de justiça que interessam a todos. Ao adotar o paradigma jurídico que estabelece procedimentos equitativos e imparciais na constituição e na defesa daquilo que é bom (justo) para a sociedade, a filosofia política do liberalismo sustenta o princípio de que o único "bem" possível que pode ser partilhado por todos é o direito.

A ética central de uma sociedade liberal é antes uma ética do direito do
que do bem. Isto é, seus princípios básicos referem-se a como a sociedade
deve responder às exigências concorrentes dos indivíduos e arbitrar entre
elas. Esses princípios incluiriam evidentemente o respeito aos direitos e às
liberdades individuais, mas no cerne de todo o conjunto que pudesse ser
chamado liberal estaria o princípio da facilitação maximal e igual. Isso não
define em primeira instância que bens a sociedade promoverá, mas antes
como ela vai determinar os bens a ser promovidos, dadas as aspirações e
exigências dos indivíduos que a compõem (TAYLOR, 2000, p. 203).

Sem recorrer a qualquer bem de fundo ético, o ordenamento jurídico determina os limites da liberdade individual, protege os direitos, especialmente as liberdades individuais, e define o alcance do poder político. Uma vez que o ponto de partida é a liberdade, a finalidade da vida não é mais a fruição política da cidadania na dimensão pública, mas a autonomia dos sujeitos na esfera privada da sociedade civil. O inevitável processo de "despolitização" da sociedade e dos conflitos sociais é decorrência da ênfase da política atrelada à garantia da pessoa com privilégios e imunidades.

O ponto crucial da noção liberal de cidadania está no pressuposto formal de que todos são iguais e livres, possibilitando, assim, a ideia da 
universalidade de sujeitos de direitos, a partir da qual qualquer indivíduo está amparado na sua capacidade de constituir visões particulares do bem. $\mathrm{O}$ interesse público e a cooperação social são significativos apenas na medida em que contribuem para incrementar e assegurar os direitos individuais, a prosperidade e felicidade particulares. Assim, as noções de bem comum, participação comunitária, consciência pública, etc. não são decisivas, mas meramente instrumentais para a realização dos interesses e direitos individuais. ${ }^{3}$

Uma consequência desse modo de ver a cidadania consiste na depreciação do seu valor vinculado à participação política, que se reduz ao mecanismo da representação. Mediante esse expediente, um terceiro - o representante - fala e age em nome do representado na esfera dos parlamentos, e o exercício da política é delegado a agentes (políticos "profissionais") em troca da estabilidade social para realizar o desenvolvimento dos interesses privados dos cidadãos.

\section{II}

Esse modo de compreender a cidadania, apesar de dominante no imaginário político das sociedades modernas, encontra resistências no pensamento de Arendt, cujo intuito consiste em enfrentar o alcance e o significado da liberdade - justamente aquilo que é estimado pelo liberalismo como valor essencial para a vida e para a cidadania. O ponto de partida da tese arendtiana é a afirmação de que a "raison d'être da política é a liberdade, e seu domínio de experiência é a ação" (ARENDT, 1979, p. 192). Se essa identidade é taxativa e atinge a razão de ser da política, a pergunta encerra, ainda, uma interrogação que remete a outra: qual a relação entre política e liberdade? Essa relação que para Arendt se dá sob a forma da identidade - permite avaliar o sentido e a finalidade da cidadania, determinando a sua diferença com o liberalismo.

A ausência desta identidade manifestou-se pela presença de um diagnóstico histórico que revelou, na modernidade, a separação entre a esfera da política e da liberdade, mediante a qual foi possível assentar o pressuposto

3 Os filósofos chamados comunitaristas não concordam com a visão empobrecida de cidadania, tal como o liberalismo político a concebe. O que se procura criticar é, justamente, a ausência de um bem substancial que congrega a comunidade com vistas à ação conjunta dos cidadãos para a promoção de um bem comum. Para os comunitaristas, apenas no seio da comunidade é que a prioridade do direito é constituída como um bem, e o é pela mediação comunitária da sua importância como um valor ético-político.

Rev. Filos., Aurora, Curitiba, v. 22, n. 30, p. 267-296, jan./jun. 2010 
da filosofia política do liberalismo na depreciação da esfera pública e cívica do viver humano em favor da existência social e econômica. A ênfase do homem como proprietário e produtor, e que se desenvolveu no âmbito da sociedade civil, é um fenômeno relativamente recente, e teve como resultado a substituição do homo politicus da tradição pelo homo economicus e socialis da era moderna. No mundo antigo, a vida social (da necessidade) era condição necessária para o pleno exercício da vida política no espaço público, possibilitando a realização de fins superiores da comunidade. Com a ascensão do homo economicus e socialis, a política, subordinada aos interesses privados dos negócios da vida socioeconômica dos indivíduos, se constitui em mero instrumento voltado para a proteção dos direitos subjetivos com vistas à sobrevivência dos indivíduos na sociedade civil e à garantia dos interesses patrimoniais.

A política e as virtudes cívicas se privatizam, deixam de ter como referência a dimensão pública, na qual a comunidade política, na perspectiva da liberdade dos antigos, promovia a constituição de uma concepção substancial da virtude e do bem, visando ao aperfeiçoamento do homem pela realização de fins morais e políticos, mediante a participação ativa do cidadão. O homem moderno prefere o ganho que a liberdade individual the propicia em troca da renúncia à ideia de um bem comum, pagando, de bom grado, o preço de viver como animal social e não mais como animal político. A participação atuante do cidadão na administração da política para a promoção do bem comum, segundo uma ordem justa para a elaboração e realização das melhores leis para a comunidade, é rejeitada como ideal cívico e inadequada aos tempos modernos. ${ }^{4}$

4 B. Constant, por exemplo, no texto Liberdade antiga e moderna (1819), desenvolve com força e claridade a distinção crucial entre a liberdade dos modernos, considerada como esfera garantida de independência pessoal e a liberdade (política) dos antigos como direito de tomar parte no governo. Além disso, afirma que a primeira é a liberdade de independência, enquanto que a segundã aquela que Rousseau pretendeu fazer reviver é a de poder participar das decisões coletivas. "A independência individual é a primeira das necessidades modernas. Em conseqüência, jamais se deve exigir o seu sacrifício para estabelecer a liberdade política." (CONSTANT, 1980, p. 506). Quanto mais o indivíduo é livre para cuidar dos seus interesses privados, tanto mais a liberdade lhe será preciosa. Daí a necessidade de "ausência" nos assuntos públicos (políticos) e a consequente necessidade da representação política. "A liberdade individual insiste Constant é a verdadeira liberdade moderna. A liberdade política é a sua garantia” (CONSTANT, 1980, p. 509).

Rev. Filos., Aurora, Curitiba, v. 22, n. 30, p. 267-296, jan./jun. 2010 
Esse deslocamento político da liberdade e da cidadania ocasionou, nos séculos XVII e XVIII, a chamada "des-politização" do indivíduo. Os homens não se definem mais como zoon politikon por natureza, mas como indivíduos privados que detêm uma peculiaridade própria a cada um: o direito natural subjetivo à liberdade individual. ${ }^{5}$ Uma vez que o ponto de partida é a liberdade de cada sujeito, a finalidade da vida não é a fruição política da cidadania na esfera pública, mas a realização dos interesses individuais na esfera privada. A associação dos indivíduos não forma mais a koinomia politiké o espaço público da comunidade que congrega os cidadãos que zelam pelo Estado - mas a societas ou a civitas, isto é, o conjunto de relações privadas de ordem econômica e juridicamente regulamentadas que os cidadãos estabelecem entre si. A vida privada e as liberdades individuais adquirem prioridade e, por isso, devem ser protegidas pela instância política, a qual ampara formas de sociabilidade voltada aos interesses privados, estimulando a instrumentalização da cidadania, mero mecanismo de defesa destes interesses.

$\mathrm{Na}$ esteira do Jusnaturalismo moderno, o liberalismo clássico aprofunda a separação entre política e liberdade. Ao confinar a liberdade no âmbito privado da vontade do indivíduo como direito subjetivo, a política foi concebida pelos modernos como um instrumento - meio que permite a satisfação das necessidades privadas dos indivíduos na sociedade, permitindo, assim, o livre desenvolvimento das forças produtivas que se efetivam na esfera do mercado - para assegurar a liberdade e garantir a sua realização.

A atribuição de um direito natural que o Jusnaturalismo confere aos indivíduos encontra sua razão de ser na liberdade que cada sujeito tem de se autorreferenciar como autor de suas próprias ações, e se constitui, precisamente, em direito subjetivo o mais elementar e essencial de todos eles. Trata-se de um atributo ou poder ( facultas) inerente à natureza racional de cada homem para agir segundo sua vontade, reforçando, assim, a crescente tendência autorreferencial da liberdade nos modernos.

5 H. Arendt, ao se reportar ao conceito aristotélico do homem como zoon politikon por natureza, chama atenção para o fato de que esta expressão não deve ser compreendida como animal socialis. Para Platão e Aristóteles, o social significava mais o instinto gregário, e não se confundia com o político, pois este caracteriza uma específica forma do viver humano. $\mathrm{O}$ social era algo que os homens tinham em comum com algumas espécies de animais. $\mathrm{O}$ simples viver junto, em sociedade, não revela o que o homem é essencialmente. A palavra social, observa Arendt, é de origem romana e não há equivalente em grego. A identificação do político com o social é latina. Para Santo Tomás, homo est naturaliter politicus, id est, socialis ("o homem é, por natureza, político, isto é, social"). 
Este significado de liberdade - a liberdade interior ou do livre arbítrio, também chamada liberdade (filosófica) da vontade - deixa de ser objeto de um viver "junto-com-os-outros" tal como os gregos vivenciaram, e passa a ser um fenômeno interno, um fato da vontade, do querer, recolhendo-se ao relacionamento do eu com o próprio eu. Na sua ambiência política original, a liberdade era um fato que se constatava no processo de interação entre os iguais. Nesse espaço comum e público, ela surge como um fenômeno da vida política, e não como algo que se origina na vontade, âmbito no qual ela passa a encontrar a forma essencial da sua manifestação, objeto de especulação filosófica e não mais de vivência política. ${ }^{6}$

Com o recuo da liberdade do indivíduo para a esfera da interioridade da sua consciência, "a época moderna, com sua crescente alienação do mundo, conduziu a uma situação em que o homem, onde quer que vá, encontra apenas a si mesmo" (ARENDT, 1979, p. 125). A condição pública da cidadania é capitulada em favor de uma individualidade que luta contra a sociedade para se defender contra as ameaças de invasão da privacidade e da liberdade. ${ }^{7}$ Embora esse diagnóstico aplique-se com mais propriedade ao liberalismo, no uso que ele faz da chamada liberdade negativa, o conceito positivo de liberdade serve, de igual modo, a uma concepção de cidadania refém de um conceito intimista de liberdade, presente no liberalismo de inspiração kantiana, por exemplo.

A interdependência entre liberdade e política tornou-se estranha com os modernos, prevalecendo a visão de que a liberdade só existe pela renúncia à política. Nossa tradição, cujos ideais políticos e morais são concretizados pelo liberalismo, deita raízes no cristianismo, o qual contribuiu de maneira decisiva para o distanciamento entre política e liberdade ao disseminar a concepção de que a política precisa ser justificada em nome de objetivos espirituais mais elevados.

6 "Em oposição a esta tradição anti-política do pensamento Ocidental - o ideal contemplativo dos filósofos clássicos, a liberdade interior elogiada pelos estóicos, a retirada cristã da política em prol da salvação, e a moderna preocupação liberal com a 'segurança', segundo a qual a liberdade individual avança quando o governo recua -, Arendt delineia sua própria concepção da unidade da liberdade e da política" (BEINER, 1984, p. 352).

7 Com os modernos, a liberdade torna-se o princípio elementar da vida humana em sociedade e passa a ser compreendida a partir da esfera da consciência individual. J. S. Mill exprime de forma exemplar o significado dessa esfera, dizendo que ela é a mais adequada para a liberdade humana. "Ela abrange primeiro o domínio íntimo da consciência, exigindo a liberdade de consciência no mais compreensivo sentido, liberdade de pensar e de sentir, liberdade absoluta de opinião e de sentimento sobre quaisquer assuntos, práticos ou especulativos, científicos, morais ou teológicos" (MILL, 1991, p. 55-56).

Rev. Filos., Aurora, Curitiba, v. 22, n. 30, p. 267-296, jan./jun. 2010 
É somente quando os cristãos primitivos, particularmente Paulo, descobriram uma espécie de liberdade que não tinha relação com a política que o conceito de liberdade pôde penetrar na história da Filosofia. A liberdade tornou-se um dos problemas principais da Filosofia quando foi vivenciada como alguma coisa que ocorria no relacionamento entre mim e mim mesmo, fora do relacionamento entre os homens (ARENDT, 1979, p. 205).

A ideia de que ser livre significava estar liberto da política veio ao mundo pelo credo cristão da liberdade como afastamento do domínio da sociedade secular, algo que não acontecia no mundo antigo. "Para que um escravo cristão, sendo cristão, permanecesse um ser humano livre, bastava que se mantivesse livre de envolvimentos seculares" (ARENDT, 1993, p. 60). Mutatis mutandis, esse é o ponto de vista do liberalismo nos tempos modernos. Hoje, ainda se defende a ideia de que a

política é um meio para um objetivo mais elevado e que se trata da liberdade dentro da política apenas porque a coisa política tem de libertar determinadas áreas. Só que a liberdade da política não é mais uma questão da minoria, mas sim, ao contrário, tornou-se uma questão da maioria que não devia nem precisava preocupar-se com os negócios do governo, ao passo que foi imposto à minoria o fardo de se preocupar com a ordem política necessária aos assuntos humanos (ARENDT, 1999, p. 70).

Ao dissociar a liberdade da política, consequência da interiorização da liberdade na consciência e vontade dos indivíduos, o liberalismo disseminou a concepção de que a liberdade começa onde a política termina. O credo liberal "quanto menos política mais liberdade" retrata a ideia de que a própria política deve ser um instrumento para assegurar a liberdade da política, uma vez que a segurança e os direitos individuais necessitam de uma ação pública que não interfira na liberdade individual. A política se restringe à defesa dos interesses privados que visam à manutenção da vida. Para isso, ela deve se circunscrever à esfera dos direitos individuais, objeto de atenção e cuidado por parte do cidadão.

Ora, onde a vida está em jogo, toda ação se encontra, por definição, sob o jugo da necessidade, e o âmbito adequado para cuidar das necessidades vitais é a gigantesca e sempre crescente esfera da vida social e econômica, 
cuja administração tem obscurecido o âmbito político desde os primórdios da época moderna (ARENDT, 1979, p. 202).

Se a visão política dos gregos não pode ser revivida, como entender a liberdade como razão de ser da política para os tempos atuais? Como é possível assumir um conceito político de liberdade e, ao mesmo tempo, incorporar o elemento moderno da autonomia da vontade sem sucumbir à visão subjetivista e individualista da liberdade? A questão é controversa e remete ao problema da politização da liberdade da vontade sem retroceder ao ideal do holismo grego e sem cair, em contrapartida, no atomismo da concepção liberal de liberdade.

Uma proposta de solução sugerida por Arendt consiste em conciliar o elemento da autonomia da vontade - na contribuição de Kant que a filósofa interpreta como experiência existencial da natalidade de um novo começo inerente à vida humana presente em ações que nascem da espontaneidade com o aspecto ético-político da práxis aristotélica da ação humana autárquica que se realiza entre homens livres no espaço público. Mesmo aceitando o elemento moderno da vontade como espontaneidade própria da contingência dos atos livres, a filósofa recusa a dimensão individualista de um sujeito autorreferencial, evidenciado pelo caráter autotélico de um querer livre, desprendido de vínculos comunitários.

Assim, o conceito arendtiano de liberdade se afasta tanto do sentido negativo como positivo, pois ambos fixam a liberdade como fenômeno circunscrito ao indivíduo, à autonomia da sua vontade, ou à proteção dos seus direitos subjetivos. Com isso, a filósofa evita a redução da liberdade a uma compreensão simplesmente filosófica - a partir da condição de um querer ou do livre arbítrio de um sujeito, "relevante somente para pessoas que vivem fora das comunidades políticas, como indivíduos solitários" (ARENDT, 1992, p. 335) - ou ao seu mero protecionismo jurídico. Tanto na concepção positiva como na negativa, a liberdade é reduzida à autorreferência de um eu: seja no seu vínculo metafísico a um eu autônomo, seja na sua dependência de proteção jurídica à sua condição de portador de direitos subjetivos.

Para a filósofa, a liberdade deve ser, antes de tudo, vivenciada no agir e na associação com os outros, isto é, como um fenômeno do espaço público que se dá na pluralidade dos seres humanos, para além da esfera privada do livre arbítrio ou dos direitos subjetivos. "Tomamos inicialmente consciência da liberdade ou do seu contrário em nosso relacionamento com os outros, e não no relacionamento com nós mesmos" (ARENDT, 1979, p. 194). Nossa 
tradição filosófica "sustenta quase unanimemente que a liberdade começa onde os homens deixaram o âmbito da vida política, habituado pela maioria, e que ela não é experimentada em associação com outras pessoas, mas sim no relacionamento com o próprio eu [...]" (ARENDT, 1979, p. 204). Com isso, a autora abre outra perspectiva de compreensão da liberdade no seu sentido eminentemente político e, consequentemente, de cidadania, e que pode ser definida como a ação de indivíduos que buscam no âmbito do espaço público e da pluralidade a realização da liberdade, e cujo valor político é possível apenas na esfera da pluralidade.

Assim como o poder é algo que surge no espaço plural dos homens e que, portanto, não pode se cristalizar no conceito jurídico da soberania de um governante, também a liberdade não deve ser reduzida à autodeterminação de um homem só, mas algo que aparece e se realiza na interação de seres humanos plurais e diferentes. Enquanto marca essencial da condição humana, a liberdade se realiza unicamente no espaço público pela mediação da cidadania. Se ela se dá na pluralidade dos seres humanos, a ideia de uma liberdade autorreferencial - na perspectiva do seu conceito positivo ou negativo contradiz com a mútua dependência dos indivíduos no viver junto. A convivência humana segue o princípio da visibilidade de seres que são capazes de ver e de ser vistos, de ouvir e de ser ouvidos, de tocar e de ser tocados. É dessa experiência radical que emerge a vida política, aquela da

recompensadora alegria que surge de estar na companhia de nossos semelhantes, de agir conjuntamente e aparecer em público; de nos inserirmos no mundo pela palavra e pelas ações, adquirindo e sustentando assim nossa identidade pessoal e iniciando algo inteiramente novo (ARENDT, 1979, p. 325).

A esfera pública é o "espaço da aparência", cuja visibilidade permite a presença de indivíduos iguais, não apenas segundo o formalismo e subjetivismo dos direitos individuais, mas, sobretudo, pela presença constante da ação humana que cria e mantém - na criação de instituições políticas democráticas - um mundo em comum. Ele é comum, não só porque se distingue dos interesses delineados segundo o modo privado das idiossincrasias de cada um, mas também porque possibilita o encontro de indivíduos com ideias diferentes que são debatidas com o objetivo de buscar alguma forma de solução democrática (não necessariamente pela imposição de uma opinião coletiva unânime) para os seus anseios e problemas da vida. Mediante o perspectivismo 
da diversidade das opiniões, comunicativamente articuladas na busca de um novo sentido da convivência humana, emerge e se afirma a cidadania. É precisamente esse espaço público de um mundo em comum que permite a unidade política na base do pluralismo. Somente assim indivíduos com diferentes pontos de vista podem ser unificados para formar uma comunidade política. ${ }^{8}$

Mas para que esse modo de entender o pluralismo seja algo possível na vida humana, é preciso compreender uma específica forma de atividade que se exerce diretamente entre os homens sem a mediação do mundo das coisas materiais. Trata-se do conceito arendtiano de ação, cujo sentido político evidencia-se pelo vínculo estreito que ela tem com a condição humana da pluralidade. ${ }^{9}$ A ação é o campo que se articula e se constitui por meio do discurso, seu elemento inseparável.

8 Ao discutir esse assunto, Mauricio D'Entreves afirma que "sua [de Arendt] concepção de interesse público, de fato, não o reduz nem à soma das preferências individuais nem à idéia de um bem comum indiferenciado. Uma vez que a pluralidade é considerada por ela como o princípio político par excellence, o bem que a comunidade tenta alcançar é sempre um bem plural, isto é, um bem que reflete tanto as diferenças entre as pessoas, ou seja, seus distintos interesses e opiniões, como o comunalismo que os vincula como cidadãos, isto é, a solidariedade e a reciprocidade que eles cultivam com seres políticos iguais" (D'ENTRÈVES, 1994, p. 151).

9 Cabe aqui relembrar a já bastante conhecida distinção arendtiana das três formas essenciais da atividade humana: o labor, o trabalho e a ação. "O labor é a atividade que corresponde ao processo biológico do corpo humano, cujo crescimento espontâneo, metabolismo e eventual declínio têm a ver com as necessidades vitais produzidas e introduzidas pelo labor no processo da vida. A condição humana do labor é a própria vida" (ARENDT, 1981, p. 15). O trabalho "é a atividade correspondente ao artificialismo da existência humana" (ARENDT, 1981, p. 15). Esta atividade refere-se à fabricação e diz respeito à produção de um fim como produto de uma determinada atividade que teve um início definido e cuja finalidade é previsível: "ela chega a um fim com seu produto final, que não só sobrevive à atividade de fabricação como daí em diante tem uma espécie de 'vida' própria" (ARENDT, 1979 , p. 91). Uma terceira forma de atividade é a ação que, ao contrário do trabalho e da fabricação, é sem si mesma desprovida de um fim como resultado de um produto. "Sob o ângulo da realização, [...] a ação parece de imediato ser mais fútil e mais frustradora do que as atividades de trabalhar e de produzir objetos. Os feitos humanos, a menos que sejam rememorados, são as coisas mais fúteis e perecíveis que existem na face da terra [...] A ação humana, projetada em uma teia de relações onde fins numerosos e antagônicos são perseguidos, quase nunca satisfaz sua intenção original [...] Quem quer que inicie um ato deve saber que apenas iniciou alguma coisa cujo fim ele não pode nunca predizer, ainda que tão somente por seu próprio feito já alterou todas as coisas e se tornou ainda mais impredizível" (ARENDT, 1979, p. 120).

Rev. Filos., Aurora, Curitiba, v. 22, n. 30, p. 267-296, jan./jun. 2010 
Sem o discurso, a ação deixaria de ser ação, pois não haveria ator; e o ator, agente do ato, só é possível se for, ao mesmo tempo, o autor das palavras. A ação que ele inicia é humanamente revelada através de palavras; e, embora o ato possa ser percebido em sua manifestação física bruta, sem acompanhamento verbal, só se torna relevante através da palavra falada na qual o autor se identifica, anuncia o que fez, faz e pretende fazer. Nenhuma outra atividade humana precisa tanto do discurso quanto a ação (ARENDT, 1981, p. 191-192).

A faculdade espiritual mais adequada no âmbito da pluralidade dos sujeitos que exercem a atividade política da ação é a capacidade de formular juízos (políticos). A autora reputa esta faculdade como a "mais política das capacidades espirituais humanas" (ARENDT, 1992). É na Crítica do Juízo de Kant que a filósofa vai buscar a forma de um juízo reflexionante, cujo alcance não foi explorado pelo filósofo da crítica como um juízo político; ou seja, de pensá-lo, seguindo a intuição kantiana, como uma espécie de sensus communis, uma forma de julgamento compreendida como atividade que opera por meio de um procedimento de pensar que se coloca no lugar de outrem, constituindo, assim, um sentido comum que pode ser aplicado à política. Nós somos capazes de melhor avaliar o nosso julgamento quando nos colocamos no lugar dos outros em diferentes perspectivas. ${ }^{10}$

Esse modo alargado de pensar, que sabe, enquanto juízo, como transcender suas próprias limitações individuais, não pode, por outro lado, funcionar em estrito isolamento ou solidão; ele necessita da presença de outros 'em cujo lugar' cumpre pensar, cujas perspectivas deve levar em consideração e sem os quais ele nunca tem oportunidade de sequer chegar a operar. Como a lógica, para ser correta, depende da presença do eu, também o juízo, para ser válido, depende da presença dos outros (ARENDT, 1979, p. 275).

${ }^{10}$ No $§ 40$ da Crítica do Juízo, Kant afirma que determinadas máximas de "sensus communis", a despeito de não fazerem parte da crítica do gosto, podem servir para a explicação dos seus princípios. Uma delas é "pensar colocando-se no lugar de qualquer outra pessoa" (KANT, 1994, p. 226). Essa máxima é a do "pensamento alargado" (erweiterte Denkungsart). Os juízos de gosto buscam persuadir, no sentido de que se pretende buscar a adesão de todos. A despeito de ser de um sujeito, estes juízos prevalecem como algo razoável para todos por um "senso de comunidade".

Rev. Filos., Aurora, Curitiba, v. 22, n. 30, p. 267-296, jan./jun. 2010 
De modo análogo ao juízo do gosto, a atividade do julgar se constitui em juízo político no sentido de se procurar o entendimento em uma determinada situação específica e particular sem ter, contudo, uma regra com critério universal de validez. Se a regra da validade universal de um juízo - circunscrito às condições de possibilidade de uma razão pura - não se aplica à pluralidade das avaliações em momentos de ruptura e crise que caracterizam a política, mediante o juízo político se "suplica" a aquiescência de todos os outros.

Esse 'suplicar' ou persuadir corresponde estreitamente ao que os gregos chamavam peithein, o discurso convincente e persuasivo tido por eles como a forma tipicamente política de falarem as pessoas umas às outras. A persuasão regulava as relações entre os cidadãos da polis porque excluía a violência física; sabiam os filósofos, porém, que ela se distinguia também de outra forma não-violenta de coerção, a coerção pela verdade (ARENDT, 1979, p. 277).

Contudo, a dignidade e o interesse pela política não mereceram dos filósofos um cuidado especial, uma vez que ela representou uma atividade da qual os "espíritos medíocres" se ocuparam. Esse menosprezo pela política deve-se, entre outros fatores, ao interesse da filosofia pelo homem solitário, instaurando com ele mesmo um diálogo quando se ocupa com o pensamento.

É da própria natureza da filosofia lidar com o homem no singular, ao passo que a política não poderia sequer ser concebida se os homens não existissem no plural. Para dizer de outro modo: as experiências do filósofo como filósofo são experiências com a solidão que, para o homem como ser político, ainda que essenciais, não deixam de ser marginais (ARENDT, 1979, p. 87).

A filósofa observa que a razão filosófica seguiu, desde os gregos, o princípio da contradição, pelo qual se estabeleceu a necessidade do pensamento para estar de acordo consigo mesmo, e argumenta que este princípio constitui a descoberta fundamental de Sócrates, enunciada por Platão no Górgias, quando asseverou: "como sou um, para mim é melhor discordar de todos que estar em discórdia comigo mesmo." Esta proposição retrata o princípio lógico, e também ético, de que a consciência não pode ser contraditória, já que eu sou um e não vou me contradizer. "O medo da contradição é o medo de fragmentar-se, de não continuar sendo um, e esta é a razão pela qual o axioma da contradição pôde tornar-se a regra fundamental do pensamento" (ARENDT, 
1993, p. 101). Do ponto de vista ético, o imperativo categórico kantiano, por exemplo, supõe uma exigência da harmonia entre a ação e a racionalidade do princípio de identidade formulado por um sujeito.

Com o juízo político, o princípio lógico do estar de acordo consigo mesmo é superado, e se busca uma "concórdia potencial com outrem" num processo de diálogo e de comunicação. Assim, a persuasão passa a ser o instrumento cognitivo por excelência no processo discursivo, no âmbito da política. Tal arte supõe o intercâmbio de perspectivas num processo de mútua compreensão da diversidade de opiniões, a partir dos diferentes pontos de vista, frequentemente opostos, de indivíduos que estão juntos e envolvidos no empreendimento comum da atuação política que culmina com a tomada de decisões. Sem recorrer à violência, o procedimento da persuasão exige um modo de expressão diverso da forma lógica, linear e não contraditória do princípio da identidade que o adágio socrático revelou como um verdadeiro axioma para o pensamento, e que a posteridade filosófica herda como verdade inefável.

A política, portanto, situa-se na dimensão discursiva do pensamento que requer a presença dos outros numa relação de pluralidade e de convivência múltipla própria da esfera pública. "Todos os aspectos da condição humana têm alguma relação com a política; mas esta pluralidade é especificamente a condição - não apenas a conditio sine qua non, mas a conditio per quam - de toda vida política" (ARENDT, 1979, p. 120). Nessa esfera, os homens agem e se relacionam por meio do diálogo e da fala, estabelecendo um espaço no qual a liberdade constitui o objetivo último da convivência que se traduz em fenômeno político. Para Arendt, a política surge "entre-os-homens" e baseiase na "capacidade de formação de opinião", pois ela é um acontecimento próprio da "pluralidade dos homens [...] e trata da convivência entre diferentes" (ARENDT, 1999, p. 21). Na Condição Humana, a autora diz que "a ação, única atividade que se exerce diretamente entre os homens sem a mediação das coisas ou da matéria, corresponde à condição humana da pluralidade, ao fato de que os homens, e não o Homem, vivem na Terra e habitam o mundo" (ARENDT, 1981, p. 15).

A condição para a ação e o discurso repousa sobre a pluralidade dos seres humanos, e se realiza sob o duplo aspecto da igualdade e da diferença. Daí a necessidade de um espaço público para a convivência (política) dos homens que, a despeito da comunidade (comum igualdade) que eles estabelecem, se diferenciam nas ações e no discurso que cada um realiza segundo a ótica particular da diversidade das opiniões. 
Embora o mundo comum seja o terreno comum a todos, os que estão presentes ocupam nele diferentes lugares, e o lugar de um não pode coincidir com o de outro, da mesma forma como dois objetos não podem ocupar o mesmo lugar no espaço. Ser visto e ouvido por todos é importante pelo fato de que todos vêem e ouvem de ângulos diferentes. [...] Somente quando as coisas podem ser vistas por muitas pessoas, numa variedade de aspectos, sem mudar a identidade, de sorte que os que estão à sua volta sabem que vêem o mesmo na mais completa diversidade, pode a realidade do mundo manifestar-se de maneira real e fidedigna (ARENDT, 1981 p. 67).

Se a política se realiza pela pluralidade, o poder político não pode ser a prerrogativa de um indivíduo que o detém, mas uma forma de agir e de aparecer do grupo e no grupo, destituída de sua aparente finalidade, que é a dominação. Ele se constituiu na capacidade dos homens atuarem em conjunto, resultado de um consenso derivado de muitos no curso comum da ação, e depende da força persuasória daqueles integram essa ação. ${ }^{11} \mathrm{O}$ poder corresponde à

habilidade humana de não apenas agir, mas de agir em uníssono, em comum acordo. O poder jamais é propriedade de um indivíduo; pertence a um grupo e existe apenas enquanto o grupo se mantiver unido. Quando dizemos que alguém está 'no poder' estamos na realidade nos referindo ao fato de encontrar-se esta pessoa investida de poder, por um certo número de pessoas, para atuar em seu nome (ARENDT, 1985, p. 24).

${ }^{11}$ Uma questão filosófica decisiva que está no centro da política é a questão do poder. Se este é uma relação entre homens, então o poder político se manifesta como uma relação de domínio de um homem sobre outro homem, e o que importa é a forma da legitimidade desse domínio por parte de que o detém. Historicamente, o Estado concentrou de modo exclusivo o poder político, uma vez que ele possui "o monopólio da legítima coerção física, com vistas ao cumprimento das leis" - na definição weberiana do poder político. A idéia predominante entre os teóricos da política retrata essa maneira de conceber o poder político, isto é, a idéia de que a sua essência consiste na capacidade de efetivar o domínio, permitindo que a violência - a mais visível é aquela originada das armas e a mais eficiente quando institucionalizada pela coerção da burocracia do Estado - se efetive como uma forma política dominante de poder. Por esta razão, a política é definida como a atividade social que garante pela força, fundada geralmente no direito, a segurança externa e a paz interna de uma unidade política. Arendt não partilha desta idéia, a qual, no fundo, remete ao traço comum de que um homem exerce o domínio sobre outro homem, não importando se pela força, autoridade ou violência, e o sujeito que possui essa qualidade é aquele que detém poder. 


\section{III}

O liberalismo defende a tese da cidadania como intitulação de direitos e difunde a ideia do seu valor instrumental: ela tem por escopo a proteção de direitos cívicos - a igualdade, as liberdades individuais - e, também, direitos sociais e até mesmo os chamados direitos difusos de quarta geração. Arendt não recusa a conquista histórica destes direitos e a importância da sua proteção jurídica. $\mathrm{O}$ que ela censura é a sua preexistência à própria condição da cidadania - esta sim condição sine qua non para ter direitos - e a forma como eles são realizados e assegurados: pela via do instrumentalismo da cidadania jurídica. O viés liberal, ainda que necessário e irrecusável, representa um empobrecimento da ideia de cidadania, um limite que o liberalismo é incapaz de superar. Ele traz, como consequência, uma ameaça ao ideal político que o conceito de cidadania deve possuir. Abre portas, assim, à recusa, ao cansaço ou desprezo pelo exercício ativo da política pelos cidadãos.

A partir da consideração dos elementos definidores da cidadania a liberdade, a ação, o espaço público e a pluralidade - Arendt amplia a sua crítica à concepção liberal de cidadania no que diz respeito à representação política, segundo a qual, o cidadão para gozar da liberdade necessita confiar ou delegar a alguém o exercício ativo da política na esfera pública. Esta noção foi compreendida como o instrumento, pelo qual o exercício político do cidadão se efetiva mediante terceiros (representantes) e, que, como conseqüência, permite a manifestação de um espaço livre e intocável para que os indivíduos se ocupem dos seus interesses na esfera privada.

A autora interpreta de modo diferente a representação política. Com base no perspectivismo kantiano do "pensamento alargado", ela admite este conceito possível apenas quando se forma "uma opinião considerando um dado tema de diferentes pontos de vista, fazendo presentes em minha mente as posições dos que estão ausentes; isto é, eu os represento" (ARENDT, 1985, p. 299). Não como o resultado da adoção cega de posições alheias, ou da empatia de sentimentos, e nem mesmo como o saldo quantitativo das opiniões das pessoas em nome das quais se fala; mas como o colocar-se no lugar do outro: tal ato significa, também, representá-lo no sentido de "de ser e pensar em minha própria identidade onde efetivamente não me encontro" (ARENDT, 1985, p. 299). A representação (política) supõe o desinteresse e a elevação da opinião representativa a um certo grau de universalidade e de desprendimento em relação aos interesses pessoais e privados, condição básica para que se possa falar em nome dos demais. 
Quanto mais posições de pessoas eu tiver presente em minha mente ao ponderar um dado problema, e quanto melhor puder imaginar como eu sentiria e pensaria se estivesse em seu lugar, mais forte será minha capacidade de pensamento representativo e mais válidas minhas conclusões finais, minha opinião. (ARENDT, 1985, p. 299).

Essa maneira de compreender a representação, contudo, é inviável se for analisada no seu uso liberal como mecanismo político de substituição e, portanto, de ausência da efetiva participação da cidadania nos assuntos públicos. Esse é o ponto crítico das sociedades "democráticas" liberais modernas, adverte Arendt. Por isso, a questão da representação constitui em "um dos mais cruciais e tormentosos temas da política moderna desde as revoluções" (ARENDT, 1988, p. 189). O problema desta forma de participação política (indireta) está na própria natureza da representação. Se os representantes, substituindo a ação popular direta, manifestam a vontade dos seus eleitores, eles o fazem na qualidade de porta-vozes privilegiados. No fundo, o mecanismo político da representação desconfia da capacidade política do povo, o qual, ainda que voluntariamente, acaba abdicando do poder e não toma parte das decisões políticas. Nesse caso, a ação política é excludente, pois os cidadãos participam do poder na esfera pública apenas de forma indireta e passiva.

Mesmo que exista comunicação entre representante e eleitor, entre nação e parlamento [...], essa comunicação nunca é entre iguais, mas entre aqueles que aspiram a governar e aqueles que consentem em ser governados. De fato, faz parte da própria natureza do sistema partidário substituir a fórmula 'governo do povo pelo povo' por 'governo do povo por uma elite emanada do povo (ARENDT, 1988, p. 221).

A tarefa do governo passa a ser assunto de especialistas voltados à administração da coisa pública; ou de demagogos e aproveitadores do cargo que buscam a realização dos interesses privados. Desse modo, a ação, enquanto finalidade da política, é negada em prol do exercício de mecanismos administrativos, ainda que estes sejam lícitos e necessários, mas apenas secundariamente. $\mathrm{Na}$ prática, uma minoria acaba deliberando ativamente sobre assuntos de interesse geral, monopolizando o governo.

Esse governo é tido como democrático na medida em que o bem-estar do povo e a felicidade individual sejam suas metas principais; mas ele pode 
ser considerado oligárquico, no sentido de que a felicidade e a liberdade públicas se tornaram, mais uma vez, privilégio da minoria (ARENDT, 1988, p. 215).

A concepção liberal de uma cidadania que se efetiva pelo mecanismo da representação torna-se, então, alvo fácil da pressão de grupos e de lobbies que procuram a defesa dos seus interesses, elidindo, assim, o sentido público da política.

\begin{abstract}
Através de grupos de pressão, tráfico de influência e outros meios, os eleitores podem, de fato, influenciar os atos de seus representantes no que diz respeito a seus interesses, isto é, podem forçá-los a realizar seus desejos, em detrimento dos desejos e interesses de outros grupos de eleitores. Em todos esses exemplos, o eleitor age impulsionado pelos interesses de sua vida privada e bem-estar pessoal, e o poder residual que ainda tem nas mãos se assemelha mais à fria coerção com que um chantagista força sua vítima à obediência do que ao poder que emerge da ação e deliberação conjugadas (ARENDT, 1988, p. 214-155).
\end{abstract}

A alternativa sugerida por Arendt ao mecanismo liberal da representação, limitada a partidos burocráticos e em esquemas jurídicos da estrutura político-estatal, consiste na criação de um sistema de conselhos, nos quais os cidadãos podem exercer ativamente a atividade política da cidadania nas diferentes instâncias deste sistema. Esta alternativa requer o envolvimento do cidadão mediante mecanismos democráticos da participação política, única forma de ação que permite suplantar a burocracia dos Estados ou das máquinas dos partidos, ou até mesmo o juridicismo da noção de soberania. O envolvimento político do cidadão significa a sua participação ativa e direta nos diversos fóruns públicos, nos quais as decisões que afetam a vida e o destino da comunidade são tomadas com respeito à pluralidade.

$\mathrm{Na}$ arena gigantesca do espaço político de uma nação, e na inadequação dos partidos políticos, os conselhos (de bairros, profissionais, das fábricas, etc) oferecem a possibilidade de criar "espaços públicos" mais adequados e democráticos. ${ }^{12}$ Contudo, esses espaços não devem representar uma ofensa a

12 Aqui, Arendt remete à experiência histórica revolucionária (da Revolução Francesa e Americana, da Comuna de Paris em 1871, dos primeiros sovietes na Rússia em 1905, dos conselhos operários na Alemanha em 1918, da Revolução Húngara de 1956) na organização 
um governo regulado por leis. A propósito da discussão de um governo totalitário, Arendt faz a defesa de um governo constitucional baseado no respeito às leis que não só asseguram que algo de inteiramente novo e imprevisível possa acontecer, como também garantem a existência de um mundo comum e a estabilidade de situações sociais necessárias para a experiência da liberdade dentro dos limites dessas mesmas leis. "Abolir as cercas da lei entre os homens - como faz a tirania - significa tirar dos homens os seus direitos e destruir a liberdade como realidade política viva; pois o espaço entre os homens, delimitado pelas leis, é o espaço vital da liberdade" (ARENDT, 1978, p. 577).

A forma de afirmação efetiva dos direitos deve ser política e consiste, primeiramente, no reconhecimento da condição do direito do indivíduo a ter direitos; e, em segundo lugar, no pleno exercício da cidadania na restauração da dignidade da política. Só assim, mediante a politização da cidadania como pressuposto para a efetividade dos direitos humanos e como a ação de cidadãos que buscam no espaço público da pluralidade a realização da liberdade, é possível superar o conceito restrito e instrumental de cidadania veiculado pelo liberalismo. Se a tese do pluralismo constitui em elemento essencial para a constituição deste conceito, a filosofia política de Arendt não nega a sua importância. Ela permite, antes, denunciar as limitações da concepção liberal do pluralismo que o restringe ao mero fato da existência da diversidade das ideias de bem. Ele deve se traduzir em diversidade política que se exprime pelo conflito de embates, próprios da atividade discursiva da esfera pública, e que, no limite, permite alcançar o consenso. Esse investimento político do pluralismo torna-se adequado a um conceito não liberal de cidadania, para cuja eficácia se faz necessária a realização da liberdade pela participação política dos cidadãos na prática do autogoverno.

espontânea dos cidadãos sob a forma de conselhos. Este novo sistema de governo caracterizado pela ação e participação coletiva pereceu em todos os lugares. Contudo, enquanto "espaços da liberdade", e diferentemente dos partidos, eles demonstraram a riqueza de órgãos espontâneos de ação que surgiram no curso da própria revolução, e brotaram do seio do povo. Retrataram, também, a esperança da transformação do Estado em uma "nova forma de governo que permitisse a cada membro da sociedade igualitária moderna se tornar um 'participante' dos assuntos públicos, que ficou sepultada nas desastrosas revoluções do século XX" (ARENDT, 1988, p. 221). A autora observa que, não obstante a experiência fugaz dos conselhos, a representação não pode ser simplesmente excluída, pois sempre há necessidade da seleção de indivíduos capazes e aptos para a ação política. Mas essa ação não pode ser feita por políticos "profissionais". Ela deve surgir no próprio processo político de viver e trabalhar juntos.

Rev. Filos., Aurora, Curitiba, v. 22, n. 30, p. 267-296, jan./jun. 2010 
O pluralismo associado à liberdade - tal como Arendt a entende na convivência política entre os homens - não exclui a ideia do conflito enquanto resultado das visões plurais que os homens têm no espaço público do viver junto. Contudo, a dimensão conflituosa da convivência humana - que alguns teóricos de inspiração hobbesiana querem atribuir à política como o seu elemento essencial - não pode ser um campo de batalha de interesses parciais e antagônicos, prevalecendo o lucro, o partidarismo e a ânsia de domínio. Reduzir o conflito à dinâmica liberal do pluralismo, que se aplica aos interesses privados dos indivíduos no âmbito da sociedade civil, resulta no deslocamento da dimensão agonística, própria à constituição do político, ao embate sócioeconômico que anima a vida da necessidade. O pluralismo, e o insolúvel antagonismo político que daí resulta, não deve se restringir ao aspecto privado da existência na diversidade das concepções de bem, mas deve, sobretudo, permear a esfera pública (política). Como palco de disputa, essa esfera politiza a pluralidade dos antagonismos, mediante a presença ativa do cidadão.

Se o pluralismo está associado à liberdade, a política deve se apresentar vinculada ao ideal da plena autonomia, sob pena de se negar o sentido da cidadania no espaço público como o âmbito da ação política que busca a realização da liberdade. E a autonomia do político se dá em dois sentidos. Primeiro, na distinção e separação entre a esfera privada (da economia) e a esfera pública (da política) como algo que difere do campo privado e social. A atividade política não constitui mero meio para alcançar outro fim, sobretudo o bem-estar social e econômico na perspectiva do instrumentalismo jurídico e político do welfare state. Esse modo de interpretar a política reduz o espaço público àquilo que Hegel chamou do "sistema das necessidades" dos indivíduos privados da sociedade civil. Antes e acima de tudo, a finalidade da política consiste na realização de princípios intrínsecos à própria dinâmica da política: a liberdade, a igualdade, o pluralismo que a cidadania deve ostentar.

Em segundo lugar, a esfera política é autônoma no sentido de que ela não tem nenhuma fundação normativa, nenhum recurso ideal para a sua constituição e compreensão, seja de princípios formais de uma teoria da justiça, seja do substancialismo comunitarista da ideia de um bem-comum. ${ }^{13}$

${ }^{13}$ Passarin d'Entrèves é de opinião que a concepção política de Arendt escapa à tradicional dicotomia entre individualismo e coletivismo, e nos ajuda a encontrar um caminho alternativo ao debate entre liberais e comunitaristas. "Para Arendt, a unidade que pode ser alcançada em uma comunidade política não é nem o resultado de uma afinidade étnica ou religiosa,

Rev. Filos., Aurora, Curitiba, v. 22, n. 30, p. 267-296, jan./jun. 2010 
Nem mesmo o recurso à moralidade - de uma consciência demasiadamente privada, subjetiva e apolítica - pode servir de parâmetro normativo para a ação política. A esfera política é autônoma porque nela a ação política possui uma referência que lhe é própria - não depende de um propósito para além dela mesmo como, por exemplo, a preservação da vida, a moralidade, ou a procura da felicidade pelos indivíduos na privacidade daquilo que Arendt denominou como o "obscurecido espaço privado."

Contudo, alguns críticos vêem nesse ideal de autonomia do político, e da ação da cidadania para a sua realização, um ponto passível de questionamento. O preço a pagar por esta sublimação quase utópica do político consiste em se deixar levar pela sua exaltação, obliterando a realidade concreta da vida social dos indivíduos. É nesse âmbito que a liberdade negativa - a pluralidade como o seu corolário - necessita de proteção jurídica, como ressaltam os defensores da perspectiva liberal de uma cidadania como intitulação de direitos. ${ }^{14}$

Como superar essa crítica se a tese forte do pensamento de Arendt é, justamente, a defesa da autonomia do político e a sua afirmação identitária com a liberdade? A ênfase arendtiana a um conceito político de cidadania que visa à realização da liberdade no espaço público não se tornaria mais real se ela, deixando de se asilar numa esfera além da realidade da vida social e dos interesses privados, operasse no âmbito da realidade sócio-econômica da sociedade? Somente assim, as questões cruciais da vida poderiam adquirir um sentido político, ainda que tratadas na ótica do cidadão comum sob o prisma dos interesses privados e da pluralidade dos pontos de vista e da diversidade das ideias particulares do bem.

nem a expressão de algum sistema comum de valores. Antes, a unidade em questão pode ser atribuída pelo compartilhamento de um espaço público e pelo conjunto de instituições políticas, e pelo engajamento em práticas e atividades que são características deste espaço e destas instituições" (D’ENTRĖVES, 1994, p. 147).

14 Wellmer, por exemplo, observa que o pensamento de Arendt, com o objetivo de 'concretizar' a autonomia do político", incorre numa "tendência reificadora" que se revela pela autoreferencialidade de uma esfera política (pública) que se descola da realidade econômica e social da sociedade. “A esfera pública é, certamente, não autônoma no sentido em que ela pode simplesmente voltar às costas para os problemas da institucionalização e asseguramento dos direitos humanos básicos, ou aos problemas da justiça social e da economia. Pois, mesmo se nós garantimos que a liberdade pública é outra coisa que a liberdade negativa, ou a proteção dos direitos individuais, ou social justiça, ou uma eficiente administração, a esfera pública ainda permaneceria flutuando no ar se ela não transformar todos esses assuntos em matéria política, fazendo deles questões de interesse público comum" (WELLMER, 2000, p. 233).

Rev. Filos., Aurora, Curitiba, v. 22, n. 30, p. 267-296, jan./jun. 2010 
Como é possível sustentar a autonomia do político - e a compreensão da cidadania como a ação política de indivíduos que buscam no âmbito do espaço público e da pluralidade a realização da liberdade - se a identificação da política com a liberdade, que o ideal de cidadania exprime, retrata o estatuto auto-referencial de algo que está imune à interferência de fatores econômicos e sociais da vida da necessidade? Em outros termos, o desafio consiste em como conciliar a perspectiva da particularidade - diante da qual o liberalismo oferece uma estratégia plausível com a tese da cidadania como intitulação de direitos para a proteção e garantia das liberdades individuais e livre manifestação do pluralismo - com a necessária autonomia da política, cuja "raison d'être é a liberdade" que o ideal de cidadania exprime e preserva para além dos limites do "obscurecido espaço privado."

Se, de um lado, a distinção entre liberdade e necessidade repousa sobre a ideia de que os interesses individuais seguem a lógica da vida social, regida pelo princípio liberal da liberdade negativa, e que não podem invadir a esfera pública, condicionando a política à economia e ao direito; de outro lado, essa distinção não pode não pode criar um abismo entre a esfera privada e pública. ${ }^{15} \mathrm{O}$ problema não está apenas na necessária distinção entre estas duas esferas, mas na articulação ou mediação de uma pela outra. Assim, de um lado, a esfera pública volta-se para a vida privada, a fim de propor um desígnio mais elevado para a cidadania marcada pela ação política para a realização da liberdade no cotidiano das questões sócio-econômicas, politizando, deste modo, a vida privada. De outro lado, a sociedade civil - e, nela, a liberdade negativa, os direitos individuais e os interesses econômicos - ancora a tendência de autonomização da política, dando-lhe uma referência social concreta. Essa articulação é possível desde que o ideal político da cidadania alcance o estatuto de um valor normativo substancial, condição indispensável para a afirmação dos direitos e liberdades individuais e do pluralismo Desse ponto de vista, ela não pode ser vista apenas como instrumento ou meio para alcançar determinados fins como o reconhecimento dos direitos individuais, ainda que moral e politicamente legítimos e necessários.

${ }^{15}$ Habermas, de modo semelhante, também critica a filósofa ao dizer que o conceito comunicativo de ação que ela apresenta não se aplica às sociedades contemporâneas pela recusa em articular na esfera política (pública) elementos econômicos e sociais presentes na esfera social. (HABERMAS, 1980, p. 109-110). Colocando em termos hegelianos essa relação, Wellmer assevera que "uma democrática forma de 'vida ética', ancorada em instituições, poderia ser chamada de 'racional' (vernünftig); mas só podemos dizer isso quando nós claramente compreendermos os problemas da construção política engendrada pelo desejo de liberdade e de autodeterminação" (WELLMER, 2000, p. 239). 
Ora, é justamente na tradição da filosofia política republicana que a cidadania ultrapassa o seu valor instrumental, definido pelo modelo dos sujeitos portadores de direitos subjetivos, e passa a ostentar uma validade em si mesma: um bem cívico determinado pela liberdade (não-dominação política e privada) dos cidadãos, e que se traduz no autogoverno da comunidade que cria as leis da res publica. São estas leis que representam uma garantia política para os direitos objetivamente constituídos a partir da vontade política da comunidade.

$\mathrm{Na}$ medida em que a liberdade é política, e para que ela possa ser uma experiência concreta na vida dos homens, é preciso que esteja vinculada tanto à existência de instituições sociais de autogoverno como à qualidade política dos cidadãos: a virtude do civismo. A exigência de virtudes cívicas e a vigilância permanente do cidadão são disposições necessárias para o cultivo e a preservação da liberdade. ${ }^{16} \mathrm{Na}$ concepção republicana, o status do indivíduo como cidadão é concebido como algo essencial para a realização do homem na comunidade, para cujo escopo torna-se necessário a participação ativa do cidadão na comunidade política como parte integrante do seu autogoverno. $\mathrm{O}$ republicanismo manteve-se fiel a certos valores da tradição como a liberdade política, o autogoverno da comunidade, o civismo, a soberania popular e a participação ativa na comunidade política mediante a compreensão da cidadania como atribuição de virtudes cívicas.

A concepção arendtiana de cidadania estaria, assim, mais próxima do conceito republicano de uma cidadania substancial constituída pela noção de virtude cívica? Se é possível aproximá-la da tradição republicana, essa relação, contudo, não significa a adesão ao entusiasmo pelo paroquialismo das pequenas comunidades, nas quais os indivíduos se identificam e levam uma vida cívica de cidadãos mergulhados no "espírito" comunitário de um povo. A despeito da sua crítica ao conceito liberal de cidadania, Arendt não pretende reascender a visão nostálgica do ideal identitário do comunitarismo republicano. Sem perder de vista determinados valores liberais ético-políticos - tais como os direitos individuais, o pluralismo, interpretados de forma a superar as suas deficiências - a concepção arendtiana de cidadania não está longe dos ideais republicanos da participação política do cidadão na res publica para servir o bem comum

${ }^{16}$ Certamente que essa concepção é de inspiração clássica, remontando ao ideal aristotélico do homem como animal político, ao republicanismo romano e, na modernidade, a Maquiavel, Harrington, Montesquieu, Rousseau e aos ideais jacobinos da Revolução Francesa e cívicos da Revolução Americana. Essa tradição enfatiza determinadas virtudes cívicas como o papel ativo da cidadania, a participação política, a igualdade, a liberdade política e a importância de um governo de leis.

Rev. Filos., Aurora, Curitiba, v. 22, n. 30, p. 267-296, jan./jun. 2010 
e assegurar a liberdade como fenômeno político, sobretudo, se esses ideais estiverem associados à tese forte da pluralidade articulada ao espaço público.

A contribuição de $\mathrm{H}$. Arendt à questão política da cidadania é, assim, bastante estimulante. Se bem entendida, ela não só fornece elementos críticos para a construção de um conceito de cidadania para além da visão estreita, juridicista e meramente instrumental que a ótica hegemônica liberal tem apresentado na sua compreensão; como também esclarece o alcance - e os limites - de uma cidadania republicana.

\section{Referências}

ARENDT, H. O sistema totalitário. Tradução de Roberto Raposo. Lisboa: Publicações Dom Quixote, 1978.

. Entre o passado e o futuro. Tradução de Mauro Barbosa de Almeida. São Paulo: Perspectiva, 1979.

A condição humana. Tradução de Roberto Raposo. Rio de Janeiro: Forense; São Paulo: EDUSP, 1981.

. Da violência. Tradução de Maria Drummond Trindade. Brasília: Ed. UnB, 1985.

. Da revolução. Tradução de Fernando Vieira e Caio N. de Toledo. São Paulo; Brasília: Ática; Ed. UnB, 1988.

. A vida do espírito: o pensar, o querer, o julgar. Tradução de Antonio Abranches e outros. Rio de Janeiro: Relume-Dumará; Ed. UFRJ, 1992.

A dignidade da política. Ensaios e conferências. Organização de Antonio Abranches. Tradução de Helena Martins e outros. Rio Janeiro: Relume-Dumará, 1993.

. O que é política. Organização de Ursula Ludz. Tradução de Reinaldo Guarany. 2. ed. Rio de Janeiro: Bertrand Brasil, 1999.

BEINER, R. Action, natality and citizenship: Hannah Arendt's concept of freedom. In: PELCZYNSKI. Z.; GRAY, J. (Ed.). Conceptions of liberty in political philosophy. London: The Athlone Press, 1984. p. 349-375.

BERLIN, I. Dois conceitos de liberdade. In: BERLIN, I. A busca do ideal: uma antologia de ensaios. Tradução de Teresa Curvelo. Lisboa: Editorial Bizâncio, 1998. p. 243-295. 
CANOVAN, M. Hannah Arendt: a reinterpretation of her political thought. Cambridge, MA: Cambridge University Press, 1992.

CONSTANT, B. De La liberté chez les modernes. Paris: Hachette, 1980.

D'ENTRÈVES, M. P. The political philosophy of Hannah Arendt. London: Routledge, 1994.

HABERMAS, J. O conceito do poder em H. Arendt. In: FREITAG, B.; ROUANET, S. P. (Org.). Habermas. São Paulo: Ática, 1980. p. 100-118.

KANT, I. Kritik der Urteilskraft. Herausgegeben von Wilhelm Weischedel, Werkausgabe Band X. Frankfurt am Main: Suhrkamp, 1994.

LOCKE, J. Segundo tratado sobre o governo. Tradução de Anoar Aiex. São Paulo: Abril Cultural, 1973. (Coleção Os Pensadores).

MILL, J. S. Sobre a liberdade. Tradução de Alberto da Rocha Barros. Petrópolis: Vozes, 1991.

RAWLS, J. O liberalismo político. Tradução de João Sedas Nunes. Lisboa: Presença, 1997.

. Justiça e democracia. Tradução de Irene A. Paternot. São Paulo: Martins Fontes, 2000.

TAYLOR, C. Argumentos filosóficos. Tradução de Adail Ubirajara Sobral. São Paulo: Loyola, 2000.

WELLMER, A. Arendt on revolution. In: VILLA, D. (Ed.). The Cambridge companion to Hannah Arendt. Cambridge, MA: Cambridge University Press, 2000. p. 220-241.

Recebido: $25 / 02 / 2010$

Received: $02 / 25 / 2010$

Aprovado: 03/05/2010

Approved: 05/03/2010 